\title{
Towards an e-learning ecologies approach to pedagogy in a post-COVID world
}

\section{Aslam Fataar}

Department of Education Policy Studies, and currently attached to the Transformation Office, Stellenbosch University, Stellenbosch, South Africa afataar@sun.ac.za

https://orcid.org/0000-0002-6880-9223

\section{Najwa Norodien-Fataar}

Fundani CHED: Curriculum Development Unit, Cape Peninsula University of Technology, Cape Town, South Africa norodien-fataarn@cput.ac.za https://orcid.org/0000-0001-8286-8089

(Received: 2 August 2021; accepted: 15 September 2021)

\section{Abstract}

In this article, part of the special COVID-19 issue of the Journal of Education, we concentrate on digital technology as one of the core dimensions of education's pandemic-related response. As the default teaching mode during the pandemic, Online Emergency Remote Teaching evoked contentious responses about future education directions in a post-COVID world. We shed light on the role of digital technology in South African education, specifically in relation to current debates on higher education. We present an argument that supports an approach based on e-learning ecologies to pedagogy to inform teaching and learning in institutional contexts. We argue that a reflexive pedagogy-led response to digital technology holds promise for creating a systemic educational approach to promoting students' critical epistemic engagement to enable them to secure viable futures.

Keywords: post-COVID pandemic, digital technology, e-learning ecologies, reflexive pedagogy, design-based learning 


\section{Introduction}

A governmentality inspired by human dignity goes beyond the protection of mere existence or the status quo. It allows us to rethink social life-to rethink globalization, ecology, the use of technology-favouring an inclusive society that places the needs of the weakest people in the foreground. (Colombo, 2020, p. 580)

A post-COVID-19 world beckons. The pandemic has impacted all our lives fundamentally. Contending with the ravages of the pandemic will be the crucial concern of our planetary existence in the immediate future. In Arundhati Roy's (2020, April 3) words, we must "imagine another world" (p. 13). This article forms part of a nascent dialogue about reimagining education in light of the pandemic, revealing our educational failures and, importantly, articulating how to pursue inclusive educational futures. Rupture or a decisive break from the structures and systems of domination is central to such a reimagination. However, the terms on which a fairer world would emerge are contested and unclear.

In this article, we respond to some of the debates raised in this special COVID-19 pandemic edition of the journal. We highlight how COVID -related educational practices and discourses have stimulated educational thinking on digital technology. Online education has rapidly come to represent an authorised vision of the default academic life under the pandemic. Fenwick et al. (2021 p. 141) have argued that "COVID-19 has forced the adoption of new digital technologies and many aspects of the experimentation and learning that the crisis has triggered will prove hard to dislodge." A pandemic pedagogy based on the rapid move to emergency remote teaching (ERT) has starkly revealed the depth of the digital divide in South Africa and the world. Middle-class institutions moved their curriculum online relatively seamlessly. Institutions serving the working poor struggled to gain access to data, devices, and digital learning systems.

Here, we offer a perspective on the productive links between digital technology and education. Ng'ambi et al. (2016) offered a 20-year review of technology-enhanced learning in South Africa. They argued that while there have been various phases of technology immersion, teaching and learning in institutions have not witnessed widescale systemic changes involving digital technology. In tandem with such a view, what is apparent is that there has not been systemic attention devoted in mainstream educational circles to understanding the substantive role of digital technology in teaching, learning, and pedagogy. Knox (2019) posited that this might be partially an outflow of digital technology being regarded as "unconventional and anti-institutional, thus [struggling with] positioning itself . . . as authentic, mainstream" (364). Knox asserted that the prevailing view of digital education is that it is largely on the periphery of core educational practice. The utilisation of digital technology may thus be regarded as marginal to educational practice. Moreover, the negative experiences of digital inequality during the pandemic may have obstructed the emergence of productive dialogue about the use of technology in mainstream educational practice. 
We examine the link between pedagogy and digital technology in education. We respond to two types of discourse that emerged prominently during the COVID-19 pandemic. The first is the scepticism concerning the use of technological modalities in education that have accelerated educational inequality during the pandemic. The second revolves around the move to remote online education currently punted by various education institutional managers and actors. We argue for inserting pedagogy into the centre of this debate or, in other words, seeing pedagogy as central to what is referred to as a hybrid ecologies approach to education (Hilli et al., 2019). A critical discussion of the terms of this pedagogical task is central to our argument.

We have arranged our response into two sections. The first is an account of online and digital technology discourses and practices that emerged in South African (higher) education during the COVID-19 pandemic. Here we aim to locate digital technology within education institutions' existing discourses and practices; this is essential for a concerted systemic approach to digital technology in education. The second presents a discussion of an elearning ecologies platform that, we argue, holds promise for instantiating a compelling pedagogical approach to digital technology in education.

\section{'Online digital technology' in (higher) educational discourse during the COVID-19 pandemic}

Many perspectives on the role of digital technology in education emerged during the pandemic lockdown that started in March 2020. These appeared in the media, in academic journals, and in statements by education associations such as teacher unions and academic groups and by individual pundits and various individual academics. The academic study of education has produced special journal issues on COVID-19 and education, such as the Southern African Review of Education, (2020) and this special issue of the Journal of Education (84, 2021). Alternation published a book on the COVID-19 pandemic and the humanities curriculum edited by Ramrathan et al., (2020).

There is consensus in the literature on education that emerged during the pandemic that ERT was characterised by digital inequality across the system. Some well-endowed mainly urban universities took their curriculum online relatively seamlessly. They extended and adapted their existing Learning Management Platforms to facilitate students' migration to digital learning and assessment. One university was ready to go live online by early April, days after the announcement of the national lockdown. Many less endowed, mainly rural, universities struggled with less-than-optimal digital learning platforms and students without devices and data (Myende \& Ndlovu, 2020). In a survey commissioned by the Department of Higher Education and Training (DHET) in 2020, students reported obstacles to remote learning such as network connectivity and data problems, lack of devices and study space as well as the lack of skills to use devices to access content online along with feelings of isolation and disconnection from lectures and peers. 
Differing perspectives by authors such as Black (2020, May 11) and Groottes (2020, May 6) in the online news platform Daily Maverick placed the spotlight starkly on the future of digital technology in education. Groottes's headline screamed, "Online to the rescue." His opinion piece advocated large-scale investment in online education as the means to secure access. He argued that those who opposed online education cannot prevail. He was supported by Watson and Calland (2020, June 10), who declared on the same platform that online learning must now be central to the way we educate the young. For them, "[E]ducation ecosystems are now and forever, digital." They suggested that online education via digital technology should now be central in addressing ongoing educational access and outcomes challenges.

Black (2020, May 11) demurred. She rejected Groottes's propagation of online learning as advocating an approach that undervalues the critical knowledge-mediating role of the teacher. She made a distinction between teaching with and teaching through technology. She argued that the latter (teaching through technology) lacks the "supposed benefits of releasing learning from the bonds of specific spaces and time" (p. 2). Favouring teaching with technology, she suggested that those proposing technology as a quick fix for education problems overlook the significance of pedagogy that is the essence of teaching expertise. The call for widespread online-based education via digital ecosystems cannot simply be brushed aside. Digital technology has been a ubiquitous, albeit uneven, feature of educational platforms for at least forty years, growing exponentially over the last twenty. Nevertheless, the call to devote attention to pedagogy is central to a consideration of the use of digital technology, a focus that has gained limited sustained attention in South African higher education.

A related set of contentions emerged among groups of academics amid the institutional politics of universities. Academic groups such as the Black Academic Caucus at the University of Cape Town expressed misgivings at the outset of the pandemic about the rapid rolling out of online teaching without sufficient preparation and resources (Black Academic Caucus statement, 2020, March 14). A group of lecturers at the coalface of South African universities expressed concern in a statement at the end of 2020 about the view that "online learning has been successful because average marks have gone up from previous years" (cited in Pikoli, 2020, December 14). They explained that their experience of the 2020 academic year was mainly of loss and that "closing campuses may have been necessary to fight the pandemic, but in the rush to online teaching we lost important face-to-face engagement with our students" (p. 2). They averred that online learning diminished meaningful student peer interaction and engagement in campus politics and that this limits the scope of their education. Learning online in impoverished domestic circumstances with problems accessing data and devices is disastrous for meaningful knowledge access and engagement.

Academics from educational development quarters attenuated this perspective. Czerniewicz (2020, April 30) and Shay (2020, May 3) suggested that the debate over online and remote education should be seen in the light of higher education's broader context and functioning. 
Shay questioned whether, in an unequal higher education sector, online remote teaching is really the problem. Condemning online teaching, according to her, is not accompanied by pragmatic solutions. Czerniewicz argued against conflating teaching with technology during the COVID crisis with the pedagogical affordances of technology. Negative experiences with digital technology should presumably not negate the positive role digital technology can play in education. Such a view aims to keep the pedagogical promise of digital technology in sight, albeit in a highly unequal higher education sector.

Two critical features of teaching online are worthy of consideration: one is the experiences of digital inequality that accompanied ERT; and the other is the mode of traditional curriculum delivery that characterised ERT.

Vandeyar (2021) and Fataar (2020, June 11) described how university lecturers and school teachers respectively adapted to meet the novel challenges associated with ERT. What emerged among educators was an account of a pedagogy of care in vulnerable school circumstances (Fataar 2020), mention of responsive humanising pedagogies by university lecturers (Strydom et al., 2020), and a description by Vandeyar (2021) of lecturers infusing their ERT with the cultivation of care, compassion, and social capital among their students. Calling attention to the "multiple and coexisting forms of inequality in higher education," Czerniewicz et al. (2020) emphasised the caring and collaborative relations between staff and students. They expressed the hope that when people and systems confront their challenges courageously, they place themselves in a position to address them.

The South African educational experience is echoed in Zheng and Walsham's (2021, p. 1) argument.

The covid-19 pandemic has unveiled and thrown a spotlight on deep-seated inequalities. ... Under the pandemic, existing socio-technical discrepancies are often magnified, and diverse forms of exclusion, marginalisation and vulnerabilities emerge. Some are more visible than others, but not all of them, the excluded and vulnerable, have a voice. Many of these disparities are mediated through digital technology, partly due to social distancing and lockdowns which replace face to face contacts with digital interactions.

ERT is entrenching class inequality in higher education. One key consequence of ERTrelated inequality is that it brought to the surface a truncated view of online learning. Because online learning is unequally experienced across the system and benefits the urban middle classes, not disadvantaged students, the logic is that online and digital technology must therefore be kept at bay. The pedagogical potential of online learning and digital technology is never brought adequately into view. ERT occludes from view the role of online modalities as a core part of the learning experience. Its educational potential and affordance are thus unable to emerge.

The second aspect of ERT that has implications for digital technology in education is its curriculum delivery mode. The traditional pedagogy of knowledge transfer has been the 
predominant mode of curriculum delivery associated with ERT. Under pressure to move their curriculum online, university lecturers rushed to load their curriculum onto their institutions' Learning Management System (LMS) platforms. Web-based applications such as TEAMs, Zoom, and Google Meet were popular for lectures where data availability allowed for the use of these applications. Materials were made available on the LMS platforms or sent via email or WhatsApp. Recorded content with low data usage for asynchronous access by students was used ubiquitously by lecturers. Bekker and Carrim's article in this issue discusses lecturers' concerns in adapting their content for online delivery. Their findings on lecturers who taught on teacher education programmes at two universities highlight how courses changed when put online; $53 \%$ of lecturers kept their content the same, while $47 \%$ changed it. Many of the latter group reduced their content. Significantly, all the lecturers indicated that they had changed their assessments. The key finding of the article is that the majority of lecturers felt that the move to online learning had compromised their teaching. This situation applies anecdotally to lecturers across the system. It aligns with the December 2020 statement signed by the group of academics referred to earlier who warned that "our experience of this year was that online platforms only allowed us to engage in limited, crisis-oriented ways, and with a fraction of our students participating meaningfully in our courses" (cited in Pikoli, 2020, p. 2).

Bekker and Carrim did not investigate the pedagogical adaptations that the lecturers made as part of their ERT. In other words, what is lacking is an understanding of how the lecturers in their sample taught the content via online modalities. The research of these two authors concentrated on lecturers' approaches to online content, not its pedagogical transfer via teaching modalities. This might be because they assumed that ERT pedagogy would involve the traditional transfer of relatively pre-packaged knowledge with clear instructions and rigid pacing and sequencing of content. Nevertheless, information about the lecturers' ETR pedagogies would have given important clues about the crucial question of the relation between digital technology and pedagogy. This would allow us to understand how students are engaging in their online learning.

Digital technology is already ubiquitous in the lives of young people. Not only are they immersed every day in social media via their smartphones and other devices, but they are also using digital technology to support their learning. Norodien-Fataar (2018) offered a detailed discussion of how university students use technologies to assist their concept acquisition and linguistic navigation. Such technology use is often carried out with little aid from, or connection to, their mainstream classes and this points to a pedagogical disconnect between formal lecturing and students' informal digital engagement to support their learning. Our position in this article is that the centrality of digital technology in ERT has placed the question of the relation of pedagogy to digital technology on the table; this is the topic we discuss more fully in the next section of this article. 


\section{Towards an e-learning ecologies approach to pedagogy}

This section is based on a brief synthesis of the work of Mary Kalantzis and Bill Cope, two Australian partner collaborators based at the University of Illinois (Urbana-Champaign), Illinois, USA. They developed their work over thirty years and have recently produced what they call an "e-learning ecologies approach to new learning and assessment" (2017, p. 1). Their essay, in a compendium of essays on COVID and education (Peters et al., 2020), caught our eye. They pointed out that ERT was based on migrating traditional lecturing practices to online platforms using video lectures, digital applications, and online tests. They suggested that lecturers had stepped back into all that was wrong with didactic modes of teaching. In other words, teaching during the COVID-19 pandemic reinforced the conventional wisdom that the "gold standard for learning is traditional face-to-face, while online is second best" (Kalantzis \& Cope, 2020, in Peters et al. 2020, p. 51). They pointed out that even if the move to online platforms during the pandemic had not been so precipitous, inperson learning was, in any event, ripe for radical transformation.

Such a transformation could productively be founded on what recent theorising on digital technology in education describes as a postdigital perspective of education. Jandric et al. (2018) explained that postdigital refers to a critical engagement with technology. Such an engagement would consider the interaction between humans and technology and how technology has become entrenched in humans' political, social, and cultural lives. Knox (2019, p. 358) defined the postdigital era as a "period of change" in human beings' relationship with technology. He alerted us to the embedded and entangled nature of technology in our existing social practices. He challenged binary notions of technology use as either an unmitigated good for optimal use in education or as having no utility in teaching and learning. In response to such a simplistic either/or view, Jandric et al. (2018, p. 895) succinctly describe the postdigital as a

'holding-to-account' of the digital that seeks to look beyond the promises of instrumental efficiencies, not to call for their end, but rather to establish a critical understanding of the very real influence of these technologies as they increasingly pervade social life.

A critical exploration of postdigital perspectives on education would focus on how digital technology is interwoven into our personal, social, and educational lives. A postdigital perspective emphasises the digital as entwined in educational practices. In other words, it emphasises the entanglement of the digital in education. We argue, therefore, that a postdigital perspective should inform a critical engagement with digital technology as constitutive of education practices. Such a perspective is currently being developed in the ongoing publication of articles in the recently established journal, Postdigital Science in Education. We argue that a postdigital perspective is a necessary precursor for developing an e-ecologies of learning pedagogical platform. 
Cope and Kalantzis's (2017) work provides a productive schema for developing a digital learning ecology. They have presented a particular account of pedagogy as central to elearning ecologies, which is a metaphor for a learning environment founded on "an ecosystem consisting of complex interaction of human, textual, discursive and spatial dynamics ... which take on a coherent, systemic form" (p. 1). Such an ecosystem would lead to changes in configurations of learning space and relationships as well as knowledge engagement and assessment. What is crucial to their argument is that the use of technology ought to be informed by appropriate approaches to pedagogy. They support the view that transformation of learning based on an e-learning ecologies approach in which digital technology plays an important role depends on the productive role of pedagogy in such an ecology.

They laid the foundation for their work during the 1990s as part of the New London Group (1996) whose members developed a multiliteracies approach to pedagogy. This work challenged the traditional view of literacy pedagogy that was based on reading and writing in page-bound, official, standard forms of national language and restricted to standard monolingual, monocultural, and rule-governed forms of language. Multiliteracies pedagogy emphasised negotiating a multiplicity of discourses founded in diverse cultures and in a plurality of texts. Crucially, the Group argued for a pedagogy that must "account for the burgeoning variety of text forms associated with information and multimedia technologies" (p. 61).

ICT-based communications media, they argued, were reshaping how we use language, and this has implications for pedagogy. Kalantzis and Cope (2012) have developed this early multiliteracies grounding more fully in their work on pedagogy in relation to digital technology since the 2000s. Based on the earlier multiliteracies foundations, pedagogy for elearning ecologies is founded on disciplined and constructive interaction between and among the principles of situating knowledge in context, overt instruction of disciplinary knowledge, critical framing of knowledge, and transforming knowledge in practice. This is based on an understanding of teaching that views students as meaning makers and designers of social futures (New London Group, 1996), not passive recipients of knowledge. In a 2012 article, they developed their proposal for

a learning charter for change in education motivated by the view that emerging digital information technologies demand greater participation than the knowledge systems of our recent past, blurring as they do the boundaries between authors and audiences, creators and consumers, knowledge makers and knowledge users. Our knowledge systems have to be transformed to acknowledge these new demands and related changes in epistemologies and ways of being. (Kalantzis \& Cope, 2012, p. 83)

Such a view implies a radically different conception of pedagogy than the one that prevailed in ERT during the pandemic and in educational discourses and practices in South African institutions more generally. We have been mired in traditional top-down and tightly scripted pedagogical orientations associated with our national school curriculum as well as the predominant approaches in higher education. Knowledge making and process-oriented 
pedagogies fly in the face of traditional knowledge-transfer pedagogies. Learner-centred teaching received a bad rap during the implementation of the conceptually inchoate outcomes-based education school curriculum (see Fataar, 2006). A culture of lock-step content transmission of standardised curricula, it seems, would stymy curriculum design and pedagogical processes.

Nevertheless, traditional pedagogies have failed to provide South Africa with an educational basis to develop the necessary critical intellectual capacity and skills to enable young people to engage in the world as productive citizens amid rapidly changing societal and economic circumstances. Knowledge-transfer-oriented curricula and pedagogy may have provided neither the knowledge engagement bases for socially just living nor the critical knowledge and skills for entry into a rapidly changing economy. More fundamentally, with respect to the focus of this article on digital technology, our current educational infrastructure and curriculum arrangements are struggling to respond to the challenge of utilising technology meaningfully. We are failing to use technology's capacity productively for multimodal meaning-making to stimulate students' intellectual engagement as knowledge producers for critical citizenship to secure viable futures.

Two aspects of an e-learning ecologies pedagogical approach are critical to such a project: the first is moving to reflexive pedagogy that views students as knowledge makers, and the second is design-based learning. Regarding reflexive pedagogy, curriculum knowledge and pedagogy are not simply about learning content. Developing the capacity to understand knowledge in context and applying knowledge in novel situations are central to e-learning ecologies. A reflexive pedagogical orientation is required in learning sites that are being transformed by digital technologies. This requires a shift from didactic pedagogy in which the balance of control of the learning environment is with the instructor and the focus is on cognition and long-term memory. A didactic pedagogy places the emphasis on "a narrow range of epistemic processes by means of which learners can demonstrate that they can replicate disciplinary knowledge. . This is a pedagogy of mimesis or knowledge replication" (Cope \& Kalantzis, 2017, p. 9, emphasis in original). Such a perspective ought to be jettisoned in favour of a reflexive pedagogy that shifts the balance of agency to a situation in which students have the scope for significant epistemic action, one in which "knowledge activity is dialogical, with backward and forward movement between instructor and students and between students and students" (p. 10). Reflexive pedagogy is not without structure or an explicit teaching role for the teacher. Teachers' pedagogy would enable a form of "scaffolding [that] makes the learning more tractable for students by changing complex and difficult tasks in ways that make these tasks accessible, manageable, and within students' zone of proximal development" (Vygotsky, 1962, in Cope \& Kalantzis, 2017, p. 10).

A reflexive pedagogy places the focus on artefacts and knowledge representations that are accessible via digital devices. Cope and Kalantzis (2017) have argued that in an era of ubiquitous knowledge access via digital technology, long-term memory is not as important as the capacity for engaging and reflexively interacting with disciplinary knowledge. The "object of learning now shifts from long-term memory to knowledge processes . . . 
involv[ing] a shift in cognition to epistemic artefacts ... [where] the focus is on the social sources of knowledge" (p. 11). E-learning ecologies are founded on the affordances that digital technologies present. Some of these affordances are ubiquitous learning, differentiated learning, and recursive feedback. In a perceptive article on the role of artificial intelligence for education, Cope et al. (2020) discuss the potential of AI computing and learning analytics for formative (and summative) individualised assessments as part of students' knowledge engagement processes.

Finally, an e-learning ecologies approach makes the possibility of pursuing a knowledge design process available to teachers. Learning design has long been promoted by educators who teach productively with digital technology (see Loveless, 2011). Hill et al. (2019) placed design at the centre of a hybrid pedagogy in learning spaces that "moves beyond the distinctions between online and offline spaces, but also challenges divisions between teacher/student roles, formal/informal contexts, analogue/digital communications media" (p. 67). The order of the activities to be used in the learning process is key to pedagogical design. The range of learning activity types, use of specific digital affordances, considerations of appropriate learning contexts, and scaffolding sequences are essential considerations in learning by design.

Cope and Kalantzis discussed knowledge processes that move between experiencing the known, experiencing the new, conceptualising by naming and conceptualising through theory as key to learning design (2017). To teach something by design is to teach it via a premeditated design focus that involves a series of explicit action stages. In such a view, teachers become designers as they select the range of activities that they will bring to their hybrid e-ecologies of learning, plan their pedagogical sequences, and reflect on the learning outcomes during and after their lessons.

Design-based pedagogy proceeds based on carefully scaffolded pedagogies. Goodyear and Dimitriadas (2013) have argued that scaffolding student practices through a combination of design and orchestration is crucial to learning design. Teachers orchestrate the learning activities by responding to student needs and feelings and the conditions in which students learn. Students' active engagement with their learning is a crucial part of designing learning. The teacher's central role in explicitly teaching disciplinary knowledge and directing learning is fundamental in digital education (Fawns, 2019). Design-based pedagogy emphasises that teachers teach bodies of knowledge and guide and move students through the various knowledge processes. The emphasis is on utilising the affordances accompanying e-learning ecologies to enable students to become reflexive knowledge interlocutors. We suggest that such a reflexive pedagogical approach is necessary to secure for students their critical citizenship roles in society.

\section{Conclusion}

Digital technology is not the silver bullet for rescuing education in post-COVID times. Its centrality in teaching and learning, however, cannot be denied or discounted. The negative 
experiences with online technology during ERT should not cloud important debates about its appropriation as core to education. The how of appropriating digital technology, not its negation, is the focus of this response article. We offer some perspectives on the recent discursive framings of digital technology during the pandemic. We argue that hesitation about engaging with the affordances of digital education should be avoided. In this light, we have developed an e-learning ecologies account as one productive perspective on digital technology in education. A multiliteracies and multimodal approach to teaching and learning is central to such an account. Our account turns on the need to shift teaching from traditional pedagogy to reflexive pedagogy as a means of stimulating knowledge acquisition and critical engagement with knowledge by students. We present digital technology as central to a reflexive pedagogy. We are not so naïve as to think that the shift to reflexive pedagogy as a cornerstone of an e-learning ecologies platform will be easily achievable over the short term.

Nevertheless, we believe that our ubiquitous interactions with the digital as constitutive of educational practices means that we must develop a generative response to teaching and learning. E-ecologies of learning processes should play an important formative role in our educational institutions. Importantly, conversations about pedagogy must now be central to these processes. Failure to do this would mean that digital technology in education overdetermines our institutional teaching platforms in such a way that we continue to favour traditional learning regimes that circulate epistemic inequality.

\section{Acknowledgement}

We would like to thank the two anonymous reviewers and the copy editor, Ann Smith, for their comments and suggestions that informed the finalisation of this article.

\section{References}

Black Academic Caucus statement. (2020). BAC requests the UCT executive to postpone the resumption of the academic year until all UCT students are registered. https://www.facebook.com/785908911530731/

Black, S. (2020, May 11). The problem with Stephen Grootes' views about online learning. Daily Maverick. https://www.dailymaverick.co.za/opinionista/2020-05-11-theproblem-with-stephen-grootes-views-about-online-learning/

Colombo, E. (2020). Human rights-inspired governmentality COVID-19 through a human dignity perspective. Critical Sociology, 47(4/5), 571-581.

Cope, B., Kalantzis, M., \& Searsmith, D. (2020.) Artificial intelligence for education: Knowledge and its assessment in AI-enabled learning ecologies, Educational Philosophy and Theory. https://doi.org/10.1080/00131857.2020.1728732

Cope, B., \& Kalantzis, M. (2017). e-Learning Ecologies; Principles of New Learning and Assessment. Routledge. 
Czerniewicz, L. (2020, April 30.) The struggle to save and remake public higher education. University World News. https://www.universityworldnews.com/post.php?story=20200428154746989

Czerniewicz, L., Agherdien, N., Badenhorst, J., Belluigi, D., Chambers, T., Muntuwenkosi, C., de Villiers, M., Felix, A., Gachago, D., Gokhale, C., Ivala, E., Kramm, N., Madiba, M., Mistri, G., Mgqwashu, E., Pallitt, N., Prinsloo, P., Solomon, K., Strydom, S., .. \& Swanepoel, M. (2020) A wake-up call: Equity, inequality and Covid-19 emergency remote teaching and learning. Postdigital Science and Education, 2, 946-967. https://doi.org/10.1007/s42438-020-00187-4

Department of Higher Education and Training (DHET). (2020). Students' access to and use of learning materials: A survey report. DHET.

Fataar, A. (2006). Policy networks in recalibrated political terrain: The case of school curriculum policy and politics in South Africa. Journal of Education Policy, 21(6), 641-659.

Fataar, A. (2020, June 11). A pedagogy of care: Teachers rise to the challenge of the new normal. Daily Maverick. https://www.dailymaverick.co.za/article/2020-06-22-apedagogy-of-care-teachers-rise-to-the-challenge-of-the-new-normal/

Fawns, T. (2019). Postdigital education in design and practice. Postdigital Science and Education, 1, 132-145. https://doi.org/10.1007/s42438-018-0021-8

Fenwick, M., McCahery, J. A., \& Vermeulen, E. P. M. (2021). Will the world ever be the same after COVID-19? Two lessons from the first global crisis of a digital age. European Business Organisation Law Review, 22, 125-145. https://doi.org/10.1007/s40804-020-00194-9

Goodyear, P., \& Dimitriadis, Y. (2013). In medias res: Reframing design for learning. Research in Learning Technology, 21, 1-13. https://doi.org/10.3402/rlt.v21i0.19909

Groottes, S. (2020, May 6). Online to the rescue. Daily Maverick. https://www.dailymaverick.co.za/article/2020-05-06-online-learning-to-the-rescue/

Hilli, C., Norgard, R., \& Aen, H. (2019). Designing hybrid learning spaces in higher education. Dansk Universitetspaedagogisk Tidsskrift, 15(27), 66-82.

Jandrić, P., Knox, J., Besley, T., Ryberg, T., Suoranta, J., \& Hayes, S. (2018). Postdigital science and education, Educational Philosophy and Theory, 50(10), 893-899. https://doi.org/10.1080/00131857.2018.1454000

Kalantzis, M., \& Cope, B. (2012). New learning: A charter for change in education. Critical Studies in Education, 53(1), 83-94. 
Knox, J. (2019). What does the 'postdigital' mean for education? Three critical perspectives on the digital, with implications for educational research and practice. Postdigital Science and Education, 1, 357-370. https://doi.org/10.1007/s42438-019-00045-y

Loveless, A. (2011). Technology, pedagogy and education: Reflections on the accomplishment of what teachers know, do and believe in a digital age. Technology, Pedagogy and Education, 20(3), 301-316. http://dx.doi.org/10.1080/1475939X.2011.610931

Myende, P., \& Ndlovu, N. (2020). COVID-19 and emergency online teaching and learning: A challenge of social justice for university rural students. In J. A. Smit, N. NdimandeHlongwa, N. Mkhize \& L. Ramrathan (Eds.), Learner and subject at the dawn of digital research-led teaching and learning in the time of COVID-19 (167-187). Humanities Institute \& CSSALL Publishers.

New London Group. (1996). A pedagogy of multiliteracies: Designing new social futures. Harvard Education Review, 66(1), 60-92.

Ng'ambi, D., Brown, C., Bozalek, V., Gachago, D., \& Wood, D. 2016. Technology enhanced teaching and learning in South African higher education - A rearview of a 20-year journey. British Journal of Educational Technology, 47(5), 843-858.

Norodien-Fataar, N. (2018). The cultivation of learning dispositions among first-generation disadvantaged students at a South African university. Educational Studies, 54(5), 505-521. https://doi.org/10.1080/00131946.2018.1509862

Peters, M., Rizvi, F., McCulloch, G., Gibbs, P., Gorur, R., Hong, M., Hwang, Y., Zipin, L., Brennan, M., Robertson, S., Quay, J., Justin Malbon, J., Taglietti, D., Barnett, R., Chengbing, W., McLaren, P., Fataar, A., Apple, R., Papastephanou, M., Burbules, N., ... \& Jackson, L. (2020). Reimagining the new pedagogical possibilities for universities post-Covid-19. Educational Philosophy and Theory. https://doi.org/10.1080/00131857.2020.1777655

Pikoli, Z. (2020, December 14). Academics reject claims that 2020 has been a success for universities. Cornerstone. https://cornerstone.ac.za/academics-reject-claims-that2020-has-been-a-success-for-universities/

Ramrathan, L., Ndimande-Hlongwa., N. Mkhize, N., \& Smit, J. (Eds.) (2020). Re-thinking the Humanities curriculum in the time of COVID-19. CSSALL Publishers.

Roy, A. (2020, April 3). Arundhati Roy: The pandemic is a portal. Financial Times. https://www.ft.com/content/10d8f5e8-74eb-11ea-95fe-fcd274e920ca

Shay, S. (2020, May 3). Online remote teaching in higher education is not the problem. Daily Maverick. https://www.dailymaverick.co.za/article/2020-05-03-online-remoteteaching-in-higher-education-is-not-the-problem/ 
Strydom, A., Herman, N., Adendorff, H., \& De Klerk, M. (2020). Responding to the necessity for change: Higher Education voices from the South during COVID-19. https://www.sun.ac.za/english/learning-teaching/ctl/Documents/Responding

Vandeyar, S. (2021) Educational transmogrification: From panicgogy to pedagogy of compassion. Teaching in Higher Education, 1-13. https://doi.org/10.1080/13562517.2021.1952568

Watson, A., \& Calland, R. (2020, June 10). A radical rethink: What Covid-19 teaches us about the future of school education. Daily Maverick. https://www.dailymaverick.co.za/opinionista/2020-06-10-a-radical-rethink-whatcovid-19-teaches-us-about-the-future-of-school-education/

Zheng, Y., \& Walsham, G. (2021). Inequality of what? An intersectional approach to digital inequality under COVD-19. Information and Organization, 31(1), 1-6. 